\title{
Evaluation of the Growth Performance, Body Composition and Survival Rate of Juvenile Snakehead (Channa marulius) Fed on Different Feeds
}

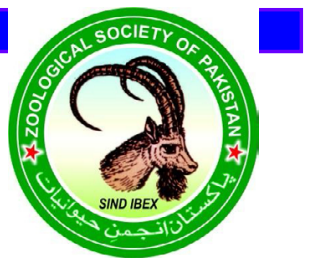

\author{
Hameeda Kalhoro', Abdul Malik ${ }^{2}$, Ghulam Abbas ${ }^{2, *}$, Illahi Bux Kalhoro ${ }^{3}$, \\ Sajjad Ali Shah ${ }^{4}$ and Haleema Kalhoro ${ }^{3}$ \\ ${ }^{1}$ Department of Fresh Water Biology and Fisheries, University of Sindh, Jamshoro, \\ Pakistan \\ ${ }^{2}$ Centre of Excellence in Marine Biology, University of Karachi, Karachi, Pakistan \\ ${ }^{3}$ Department of Anatomy and Histology, Faculty of Animal Husbandry and \\ Veterinary Science, Sindh Agriculture University, Tando Jam, Pakistan \\ ${ }^{4}$ Directorate of Fisheries Sindh, Livestock and Fisheries Department, Governm \\ of Sindh, Pakistan

\section{A B S T R A C T} \\ This research was done to determine the influence of various feeds of rowth increment, ody \\ constituents and survival rate of snakehead (Channa marulius) cultured in pl c tanks ( 19 liters water \\ carrying capacity each). Fish juveniles (length: $10.63 \pm 0.980 \mathrm{~cm}$, weight: $9.030 \quad 40 \mathrm{~g}$ ) w stocked after \\ acclimatization. A total of 3 treatments were tested following 2 tions i.e. $\mathrm{r}$ ( $\mathrm{T}_{1}$, Squid \\ feed), second treatment ( $T_{2}$ Tubifex feed) and third treatment ( $\mathrm{T}$ ed). Juvenlles were fed with \\ $5 \%$ of total biomass twice in a day. At the end, higher growth incre ${ }^{\dagger}$ sund such as length and \\ weight in average, $T_{1}=15.01 \pm 0.33 \mathrm{~cm}$ and $15.80 \pm 0.0^{\prime} 14.13 \pm$ and $13.35 \pm 0.67 \mathrm{~g}$ whereas in
} $\mathrm{T}_{2}=11.80 \pm 0.96 \mathrm{~cm}$ and $10.47 \pm 1.19 \mathrm{~g}$ lower growt for 1. Speci growth rate (SGR) were obtained $1.160,0.960$ and 1.110 in $\mathrm{T}_{1}, \mathrm{~T}_{2}$ and $\mathrm{T}_{3}$ individu statisucally from all treatment groups. Similar situation was found in values of ${ }^{\prime}$ onditio ctor remained as $0.610,0.720$ and 0.620 for T1, T2 and T3, respectively. Fee fersion (Fo were found to be non-significant among all treatments $(\mathrm{P}>0.05)$. Survival rate we.e $90, \quad \mathrm{~T}_{1}$ which as highest than $\mathrm{T}_{2}(50 \%)$ and $\mathrm{T}_{3}(80 \%)$. Water

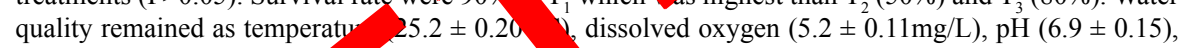
ammonia $(0.48 \pm 0.021 \mathrm{~m}$, and hardness $(1,2.4 \mathrm{mg} / \mathrm{L})$. Our results indicated that better growth increment can be achieved so or pellet feed and so it is suggested that in similar culture conditions of Snakehead will bo-more p, able on llet feed followed by squid feed.

\begin{abstract}
A quaculture plays an important role not only in meeting demand for meat, it is also exclusively recognized as the fastest food producing industry. It contributes more than 19 million tons yearly through aquaculture (Baruah et al., 2004; Iqbal et al., 2014). Aquaculture industry offers a huge amount of protein in the shape of fish-meal, which is used as a food for aquatic animals, providing income source for coastal population of less developed countries. This industry also plays an important role in enhancing the earning source for the fishermen (Iqbal et al., 2014; Soto-Zarazua et al., 2010; Suloma and Ogata, 2006).

\footnotetext{
* Corresponding author: ghulamabbas@uok.edu.pk 0030-9923/2017/0005-1871\$9.00/0

Copyright 2017 Zoological Society of Pakistan
}

The snakehead (Channa marulius) is extremely meateating predatory inland water teleost which is commonly spread in Asian as well as African countries. Channa species can flourish in lentic and lotic water bodies and also in weed crowded narrow and less oxygenated water due to the presence of accessory breathing organs; they are the best and admirable table size fish in the South East Asian countries (Zakaria et al., 2007; Cruz et al., 1980). This specie is popular in Pakistan due to its delicious taste and recovering qualities for ill and weak people physically and mentally (Hafeez-ur-Rehman et al., 2017; Khanna, 1978). This specie have acceptable white meat having non intra-muscular skeletons and is believed that this contains curative and strength-giving elements, and is therefore particularly provided to old people and those in recoveries (Ling, 1977; Yakoob and Ali, 1992). However, this specie is carnivore in feeding nature but easily can eat and digest 
foods prepared from various plant by-products with high protein contents. It could be fruitfully culture in mono as well as in polyculture system with indigenous fish species (Hafeez-ur-Rehman et al., 2017). Whereas in monoculture, this species can be reared on huge quantities because off air breathing ability surviving at low oxygen levels (Singh et al., 1986). Snakehead farming is appreciated when its seed is available particularly during monsoon (Hanifa et al., 2000; Marimuthu et al., 2001a, b; Mollah et al., 2009). Mostly, the snakehead culture on commercial basis depends on wild fry, which are formerly proficient to agree for taking compound feed manufactured from fish meal and plant by products like rice bran or wheat flour (Diana et al., 1985; Kulachi et al., 2014). In Pakistan, Snakehead is considered as market value target species into the aquaculture system, being indigenous and having potential to survive under variety of stressful freshwater conditions. Nothing has been done on Snakehead culture to encourage its aquaculture practices. Therefore, this study was carried out to investigate appropriate diet for best growth of Channa marulius fingerlings reared in captive environment.

Table I.- Ingredients of fish test diet (dry matter basis

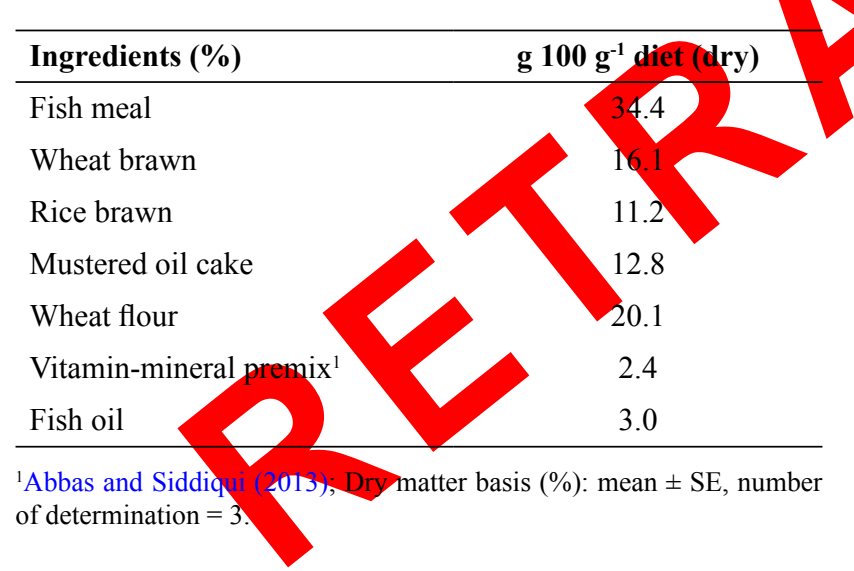

\section{MATERIALS AND METHODS}

The present study was started from $10^{\text {th }}$ October 2014 to $26^{\text {th }}$ November 2014 in plastic tanks (42.5 liters of water holding capacity) in the laboratory of Freshwater Biology and Fisheries, University of Sindh. There were three treatments having two replicates. Three different feeds i.e. Squid meat obtained from the Karachi Fish Harbour, Tubifex feed obtained from the Ornamental Market Karachi and pellet feed was formulated using ingredients purchased from the Local Market of Jamshoro (Table I). Two replicates of each treatment were stocked with 60 fingerlings $(10.63 \pm 0.98 \mathrm{~cm}, 9.03 \pm 1.4 \mathrm{~g})$. The fingerlings of Snakehead were collected from the wild, acclimatized for one week before stocking into the experimental tanks. After that juveniles were equally distributed in experimental tanks; all tanks were cleaned with $\mathrm{KMnO}_{4}$. Tanks were covered with net to stop escaping out and artificial oxygen was provided through aeration into the tanks. Fish were fed 5 percent of total biomass two times in a day $(09.00$ and 14.00) for 48 days. Pelleted feed was formulated and organized from indigenous available ingredients such as fish meal (FM), mustard oil-cake (MOC), groundnut (GN), rice bran ( $\mathrm{RB})$, wheat bran (WB), wheat flour (WF) and vitamin premix were crushed and sieved with net having $0.5 \mathrm{~mm}$ mesh size. After weighing ingredients according to formula, all ingredients were homogenized and passed from pelleted machine to make with $1 \mathrm{~mm}$ diameter pellet. The chemical composition of test diets is shown in Table II. Feed was offered daily and after 2 b uneaten feed was siphoned. The daily ration was reset appropriately after each sampling subsequently, all experimental tanks were cleaned properly at the time of sampling. Length size of experimental fish were calculated with the help of a foot scale in $\mathrm{cm}$. The weight increment was calculated through oveable electric weight machine model (AK-3000H AFD) nearest $1 \mathrm{~g}$. Water quality of the experimental tanks was monitored daily according to Boyd and Tucker (1992).

Table II.- Nutritive value of experimental diet used for Snakehead, Channa marulius juveniles for 48 days rearing period.

\begin{tabular}{lccc}
\hline Parameters & Squid & Tubifex & Pellet \\
\hline Crude protein & $76.1 \pm 0.8$ & $52.0 \pm 0.4$ & $39.7 \pm 0.3$ \\
Crude lipid & $2.7 \pm 0.2$ & --- & $5.7 \pm 0.2$ \\
Crude fiber & --- & $2.0 \pm 0.1$ & 5.8 \\
Crude fat & $1.2 \pm 0.1$ & $12.0 \pm 0.2$ & --- \\
Moisture & --- & $5.0 \pm 0.1$ & 7.0 \\
Ash & $1.3 \pm 0.2$ & $12.0 \pm 0.1$ & $7.1 \pm 0.3$ \\
Minerals & $1.9 \pm 0.1$ & --- & --- \\
\hline
\end{tabular}

Data calculations/analysis

ANOVA was applied for determination of relative increment in growth and surviving percentage of Snakehead, Channa marulius juveniles. These are followed by statistical analysis through Duncan test at $95 \%$ confidence level.

\section{RESULTS}

The parameters of growth increment were shown as weight gain (WG), average daily weight gain (ADWG), specific growth rate (SGR), food conversion ratio (FCR), 
survival rate (SR) and condition factor (CF) in Table III. Fish growth varied among all treatments. Higher growth in relation to increase in length and weight was found in $\mathrm{T}_{1}$ and T3 (Fig. 1A, C), while growth of fish was lower in T2 (Fig. 1B). SGR was recorded as $1.160,0.960$ and 1.110 in $\mathrm{T}_{1}, \mathrm{~T}_{2}$ and $\mathrm{T}_{3}$ individually which were different among all treatment $(P<0.01)$. Condition factor remained similar among treatments. Similar condition was found in the values of FCR. The rate of survival was found different in all treatments $(P<0.01)$. Maximum percentage of survival was obtained in $\mathrm{T}_{1}(90 \%)$ fed upon squid feed than $\mathrm{T}_{2}$ $(50 \%)$ and $\mathrm{T}_{3}(80 \%)$ which are significantly different from each other $(\mathrm{P}<0.05)$.

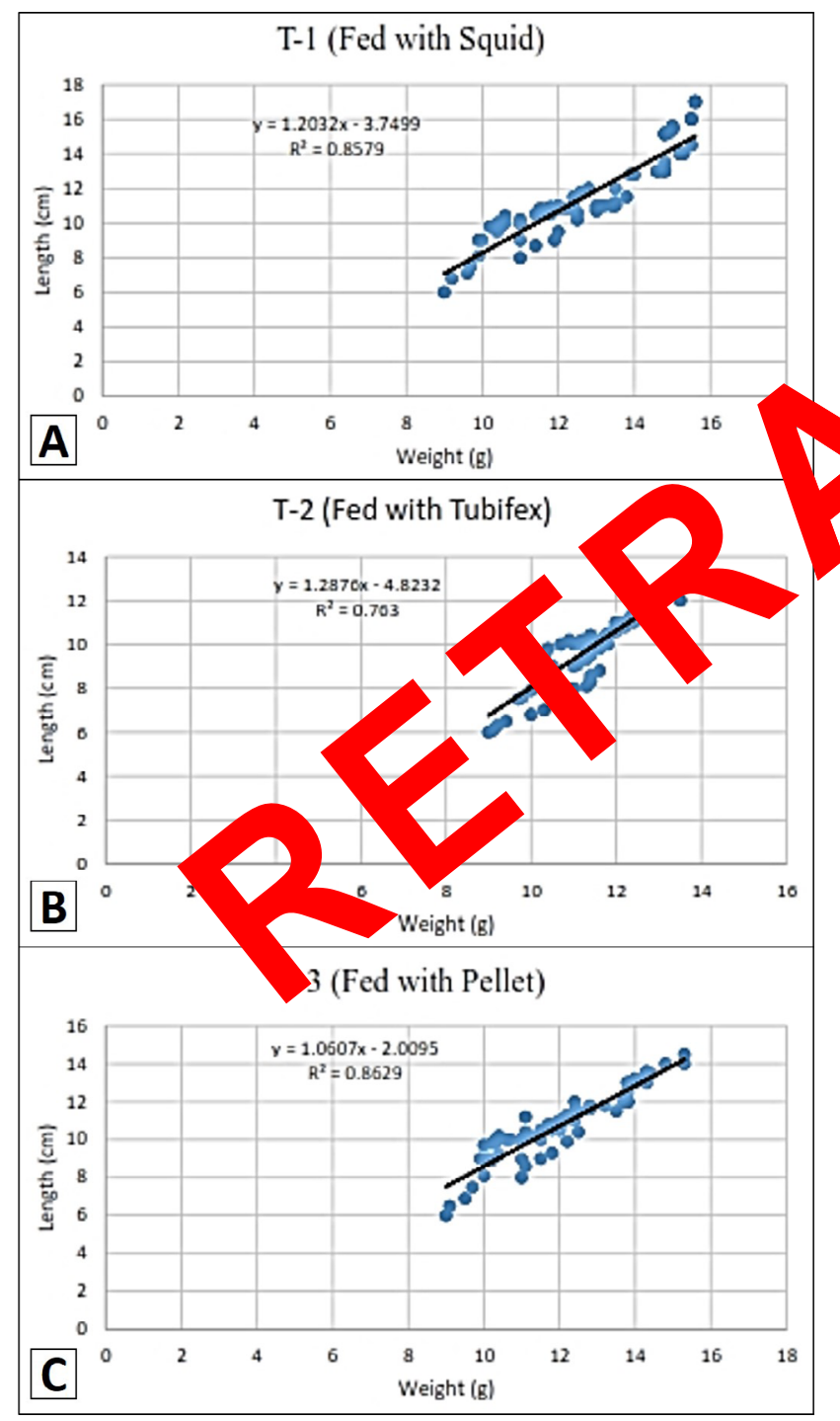

Fig. 1. Regression on the length and weight of snakehead (Channa marulius) juveniles fed with squid (A), Tubifex (B) and pelleted feed (C) for 48 days.
Table III.- Growth parameters of snakehead (Channa marulius) fish reared for 48 days.

\begin{tabular}{|c|c|c|c|}
\hline \multirow[t]{2}{*}{ Parameters } & \multicolumn{3}{|c|}{ Diets } \\
\hline & $\begin{array}{c}\text { T1 } \\
\text { (Squid) }\end{array}$ & $\begin{array}{c}\text { T2 } \\
\text { (Tubifex) }\end{array}$ & $\begin{array}{c}\text { T3 } \\
\text { (Pellet feed) }\end{array}$ \\
\hline Mean final weight (g) & $15.8 \pm 0.70^{\mathrm{a}}$ & $10.47 \pm 1.18^{\mathrm{b}}$ & $13.35 \pm 0.66^{\mathrm{c}}$ \\
\hline Mean final length (cm) & $15.0 \pm 0.33^{\mathrm{a}}$ & $11.81 \pm 0.95^{\mathrm{b}}$ & $14.13 \pm 0.75^{\mathrm{c}}$ \\
\hline Weight gain (g) & $6.77 \pm 0.0^{\mathrm{a}}$ & $1.44 \pm 0.0^{\mathrm{c}}$ & $4.32 \pm 0.0^{\mathrm{b}}$ \\
\hline ADWG & $0.35 \pm 0.0^{\mathrm{a}}$ & $0.22 \pm 0.0^{\mathrm{c}}$ & $0.28 \pm 0.0^{\mathrm{b}}$ \\
\hline SGR & $1.16 \pm 0.01^{\mathrm{a}}$ & $0.96 \pm 0.02^{b}$ & $1.11 \pm 0.01^{\mathrm{a}}$ \\
\hline FCR & & $0.0^{\mathrm{a}}$ & $0.4 \pm 0.0^{\mathrm{a}}$ \\
\hline Survival rate $(\%)$ & & $.02^{\mathrm{c}}$ & $80 \pm 0.02^{b}$ \\
\hline $\mathrm{CF}$ & & 0.05 & $0.62 \pm 0.11^{\mathrm{a}}$ \\
\hline$F=$ & & $\begin{array}{l}\text { sts of } 10 \text { fisl } \\
\text { are signific } \\
\text { he fish was } \\
\text { final weigh } \\
\text { re period (d. } \\
\text { ht-Log initi } \\
\text { f fish/Initial }\end{array}$ & $\begin{array}{l}\text { her replicate) } \\
\text { cantly different } \\
9.03 \pm 1.4 \mathrm{~g} \text { and } \\
\text { t-Mean initial } \\
\text { ays). FCR }=\text { Wet } \\
\text { al weight } \times 100 / \\
\text { number of fish }\end{array}$ \\
\hline
\end{tabular}

Table IV.- Whole body composition (\% dry weight is) of Snakehead, Channa marulius juveniles fed at different feeds for $\mathbf{4 8}$ days.

\begin{tabular}{lccc}
\hline Parameters & Squid & Tubifex & Pellet \\
\hline Protein content & $21.5 \pm 0.4^{\mathrm{a}}$ & $20.9 \pm 0.5^{\mathrm{b}}$ & $21.4 \pm 0.3^{\mathrm{a}}$ \\
Fat & $17.3 \pm 0.2^{\mathrm{a}}$ & $17.1 \pm 0.3^{\mathrm{a}}$ & $17.2 \pm 0.2^{\mathrm{a}}$ \\
Moisture content & $51.4 \pm 0.7^{\mathrm{a}}$ & $50.6 \pm 0.5^{\mathrm{b}}$ & $51.3 \pm 0.6^{\mathrm{a}}$ \\
Ash & $7.67 \pm 0.3^{\mathrm{a}}$ & $7.52 \pm 0.4^{\mathrm{b}}$ & $7.66 \pm 0.3^{\mathrm{a}}$ \\
Crude Fiber & $0.04 \pm 0.01^{\mathrm{a}}$ & $0.02 \pm 0.01^{\mathrm{c}}$ & $0.03 \pm 0.01^{\mathrm{b}}$ \\
\hline
\end{tabular}

Whole body composition (\% dry weight basis) were analysis, protein contents were not significantly $(P>0.05)$ affected with squid and pellet feed and significantly affected on tubifex feed (Table IV). Moisture content of fish fed on squid and pellet were not significantly affected $(P<0.05)$ and affected fed on tubifex. Fat, ash and crude fiber were not significantly different affected on different feed.

Water quality parameters were determined throughout the experiment were found non-significant among all treatments, $P>0.05$; temperature of the water, $25.2 \pm 0.20$ ${ }^{\circ} \mathrm{C}$, concentration of dissolved oxygen was $5.2 \pm 0.11 \mathrm{mg} / \mathrm{L}$, $\mathrm{pH}$ was $6.90 \pm 0.15$, ammonia concentration was $0.48 \pm$ $0.021 \mathrm{mg} / \mathrm{L}$ and water-hardness were found $118 \pm 2.4 \mathrm{mg} / \mathrm{L}$ (Table V). 
Table V.- Water quality parameters of the snakehead (Channa marulius) fish reared for 48 days.

\begin{tabular}{lccccc}
\hline \multirow{2}{*}{ Treatments } & \multicolumn{5}{c}{ Parameters } \\
\cline { 2 - 6 } & Temperature $\left({ }^{\circ} \mathbf{C}\right)$ & Dissolve Oxygen $(\mathbf{m g} / \mathbf{L})$ & $\mathbf{p H ~} \mathbf{( m g} / \mathbf{L})$ & Ammonia $(\mathbf{m g} / \mathbf{L})$ & Hardness $(\mathbf{m g} / \mathbf{L})$ \\
\hline T-1 (Squid) & $25.2 \pm 0.20^{\mathrm{a}}$ & $5.2 \pm 0.11^{\mathrm{a}}$ & $6.9 \pm 0.15^{\mathrm{a}}$ & $0.42 \pm 0.03^{\mathrm{a}}$ & $116 \pm 2.0^{\mathrm{a}}$ \\
T-2 (Tubifex) & $25.1 \pm 0.17^{\mathrm{a}}$ & $4.9 \pm 0.25^{\mathrm{a}}$ & $7.4 \pm 0.20^{\mathrm{a}}$ & $0.48 \pm 0.02^{\mathrm{a}}$ & $120 \pm 2.6^{\mathrm{a}}$ \\
T-3 (Pellet) & $25.3 \pm 0.14^{\mathrm{a}}$ & $5.1 \pm 0.26^{\mathrm{a}}$ & $7.6 \pm 0.15^{\mathrm{a}}$ & $0.50 \pm 0.03^{\mathrm{a}}$ & $118 \pm 2.4^{\mathrm{a}}$ \\
Mean values & $25.2 \pm 0.17^{\mathrm{a}}$ & $5.1 \pm 0.2^{\mathrm{a}}$ & $7.3 \pm 0.16^{\mathrm{a}}$ & $0.46 \pm 0.02^{\mathrm{a}}$ & $118 \pm 2.3^{\mathrm{a}}$ \\
\hline
\end{tabular}

Similar superscripts indicate no statically difference among treatments.

\section{DISCUSSION}

Chana marulius locally called Chitto Shakur or Chitti Mondhi, is highly carnivore in feeding habit and been identified cannibalistic fish by several researchers (Sonawane et al., 2012). It has also been documented that carnivorous fish require high protein diet as compared to herbivore fish (Ashraf et al., 2011; Wee, 1982). Findings of the present study presented maximum growthincrement like mean weight, $\mathrm{WG}$, mean $\mathrm{WG}$ per day and SGR percentage were presented in $\mathrm{T}_{1}$-meat of squid and $\mathrm{T}_{3}$-Pellet feed, whereas lower growth-increment observed in $\mathrm{T}_{2}$ fed on Tubifex. These outcomes are parallet with outcomes of Srivastava et al. (2012) and Mohan and Samantaray (1996). They obtained higher growt increment of Channa striata fry fed with formulated feed Similar results have found on juveniles of Channa striata (Srivastava et al., 2012; Giri et al. 2003; Wee, 1986), milk fish, Chanos chanos (Srivastara et ak, 2012; Lim et al., 1979), Channa micropeltes, (Srivastava et al., 2012; Wee and Tacon, 1982), Common carp, Cyprinus carpio (Ogino and Saito, 1970), Icthalurus punctatus (Prather and Lovell, 1973) Epinephelus tauvina (Teng etal., 1978), and tilapia S. mossambicus (Jauncey, 1982). In the current outcomes, highest survival rate $i . e .90 \%$ and $80 \%$ fed with squid meat and pellet feed was detected respectively whereas lower survival rate i.e. $50 \%$ was found with tubifex feed these results are in contrast with the results of Giri et al. (2003); they found maximum survival rate of Jarko or Mallee fish larvae fed on natural food and dry food. Significant death rate and poorest growth rate were found in those fishes which were supplied with plankton. It was generally observed that the sluggish growing fish are omnivorous and rapid growers are carnivorous (van Densen, 1985; Jesu et al., 2001). It is recognized that higher cannibalistic character present in Channa species at all ages of life and due to this main cause, less survival rate was recoded throughout their culturing ( $\mathrm{Ng}$ and Lim, 1990). According to Diana et al. (1985), in cannibalism though shooters have ability to target on 2 to 3 inches size feed conversion ratio (FCR) was non-significantly different for all treatment groups.
These findings contradict with the outcomes reported by Daudpota et al. (2014) and lesser as compared with the values stated by Das and Ray 1989), Islam (2002), Islam et al. (2002) and Matjais et al. (1994). Qin and Fast (2003) reported that snakehead fed with compound feed required 1.0. Feed conversion ratio value which is higher than those gained in this study. The values of $\mathrm{K}$ were significant in second treatment and lower in first and third treatments. These outcomes are lesser than the findings of Malik et al. 2017), Shah et al. (2014), Daudpota et al. (2014) nd Moreira et al. (2008). The parameters regarding water quality were observed in the range of acceptable values for warm water fish farming and similar with pervious results of Shah et al. (2014), Daudpota et al. (2014), Hannibal (2011), Narejo et al. (2010) and Wee (1982).

In the light of present finding that the effects of different feeds on Snakehead, Channa marulius bodycomposition, protein-content in fish flesh remained at a relatively stable level. It comes into view that the lowest frequency could provide dietary protein at or slightly above the maintenance level of the fish as recommended by Hung and Lutes (1987), Mehboob et al. (1996), Michelle et al. (2004), Qin and Fast (1997) and Cho et al. (2003).

\section{CONCLUSION}

In the present study, highest growth increment was achieved with squid meat. Thus, it is recommended that for commercial scale this species can be culture on pellet feed would be cost effective and more profitable than culture on the feed of squid meat.

Statement of conflict of interest

Authors have declared no conflict of interest.

\section{REFERENCES}

Abbas, G. and Siddiqui, P.J.A., 2013. The effects of varying dietary protein level on growth, feed conversion, body composition and apparent digestibility coefficient of juvenile mangrove red 
snapper, Lutjanus argentimaculatus (Forsskal 1775). Aquacult. Res., 44: 807-818. https://doi. org/10.1111/j.1365-2109.2012.03096.x

Ashraf, M., Zafar, A. and Naeem, M., 2011. Comparative studies on the seasonal variations in the nutritional values of three carnivorous fish species. Int. J. Agric. Biol., 13: 701-706.

Baruah, K., Sahu, N.P., Pal, A.K. and Debnath, D., 2004. Dietary phytase: An ideal approach for a cost effective and low-polluting aquafeed. World Fish Center Quart., 27: 15-19.

Boyd, C.E. and Tucker, C.S., 1992. Water quality and pond soil analyses for aquaculture. Alabama Agricultural Experiment Station, Auburn University, Alabama, pp. 183.

Cho, S.H., Lim, Y.S., Lee, J.H., Lee, J.K. and Park, S., 2003. Effects of feeding rate and feeding frequency on survival, growth, and body composition of post-larvae Plecoglossus altivelis. J. World Aquacult. Soc., 34: 85-91. https://doi. org/10.1111/j.1749-7345.2003.tb00042.x

Cruz, E.M. and Laudencia, I.L., 1980. Poly-culture of milkfish (Chanos chanos Forskal), all male Nile tilapia (Tilapia nilotica) and snakehead (Ophiocephalus striatus) in freshwater ponds with supplemental feeding. Aquaculture, 20. 231-23 https://doi.org/10.1016/0044-8486(80)90113-1

Das, I. and Ray, A.K., 1989. Growth performance of Indian major carps Labeo rohita (Ham.) on duckweed incorporated pelleted feed: A preliminary study. J. Inland Fish., 21: 1-6.

Daudpota, A.M., Kahoro, I.B., Shah, S.A., Kalhoro, H. and Abbas, G., 2014. Effect of stocking densities on growth, production and survival rate of red tilapia in hapa at fish hatchery Chilya Thatta, Sindh, Pakistan. J Fish., 2: 180-186. https://doi. org/10.17017/jfish.v2i3.2014.45

Diana, J.S, Chang, W.Y.B, Ottey, D.R. and Chuapoehuk, W., 1985. Production systems for commonly cultured freshwater fishes of Southeast Asia. International Program Report, number 7, Great Lake and Marine Water Center, University of Michigan, Ann Arbor, Michigan, U.S.A., pp. 75-79.

Giri, S.S., Sahoo, S.K., Sahu, B.B., Sahu, A.K., Mohanty, S.N. and Yappan, S.A., 2003. Larval survival and growth in Wallago attu (Bloch and Schneider): effects of light, photoperiod and feeding regimes. Aquaculture, 213: 151-161. https://doi. org/10.1016/S0044-8486(02)00012-1

Haniffa, M.A., Merlin, T. and Mohamed, J.S., 2000. Induced spawning of the striped murrel Channa Striatus using pituitary extracts, human chronic gonadotropin and luteinizing hormone releasing hormone analogue and ovaprim, Acta Ich. Piscat., 30: 53-60. https://doi.org/10.3750/AIP2000.30.1.04

Hannibal, M.C., Amparo L.F. and Aurelio, A.C., 2011. Effect of stocking density on growth performance, survival and production of silver pompano, Trachinotus blochii, (Lacépède, 1801) in Marine Floating Cages. Asian Fish. Sci., 24: 321-330.

Hung, S.S.O. and Lutes, P.B., 1987. Optimum feeding rate of hatchery-product juvenile white sturgeon (Acipenser transmontanus) at $20^{\circ} \mathrm{C}$. Aquaculture, 65: 307-317. https://doi.org/10.1016/00448486(87)90243-2

Hafeez-ur-Rehman, M., Abbas, F., Ashraf, M., Narejo, N.T., Iqbal, K.J., Abbas, G. and Andleeb, S., 2017. Effect of different dietary protein levels on egg development and its response to inducing agents during induced spawning of Channa marulius. Pakistan J. Zool., 49: 337-343. https://doi. org/10.17582/journal.pjz/2017.49.1.337.343

m, M.S., 2002. Evaluation of supplementary feeds for semi-intensive pond culture of mahaseer, Tor putitora (Hamilton). Aquaculture, 212: 263-276. ://doi.org/10.1016/S0044-8486(02)00194-1

Iqbal, K.J., Ashraf, M., Abbas, F., Javid, A., Hafeez-urRehman, M., Abbas, S., Rasool, F., Khan, N., Khan, S.A. and Altaf, A., 2014. Effect of plant-fishmeal and plant by-product based feed on growth, body composition and organoleptic flesh qualities of Labeo rohita, Pakistan J. Zool., 46: 253-260.

Ismal, M.S., Dewan, S., Hussain, M.G., Hossain, M.A. and Mazid, M.A., 2002. Feed utilization and wastage in semi-intensive pond culture of mahaseer, Tor putitora (Ham). Bangladesh J. Fish. Res., 6: 1-9.

Jauncey, K., 1982. The effect of varying dietary protein level on the growth, food conversion, protein utilization and body composition of juvenile tilapia Sarotherodon mossambicus. Aquaculture, 27: 4354. https://doi.org/10.1016/0044-8486(82)90108-9

Jesu, A., Arockia, R., Muruganandam, M., Marimuthu, K. and Haniffa, M.A., 2001. Influence of aquatic weed (Lemnia minor) on growth and survival of the fingerlings Channa Striatus. Centre for Aquaculture Research and Extension. St. Xavier's College, Palayamkottai-627 002, Tamil Nadu. India. J. Inland Fish. Soc. India, 33: 59-64.

Khanna, S.S., 1978. An introduction to fishes, Second Edition. Central Book Dept, Allahabad, pp. 428.

Kulachi, S., Farooq, A., Umer, K., Narejo, N.T., Ali, M., Ahmed, I. and Iqbal, R., 2014. Evolution of meat quality of Channa marulius under different cultural 
conditions. Sindh Univ. Res. J. (Sci. Ser.), 46: 2272230.

Lim, C., Sukhawongs, S. and Pascual, F.P., 1979. A preliminary study on the protein requirement of Chanos chaonos (Forsskal) fry in a controlled environment. Aquaculture, 17: 195-201. https://doi. org/10.1016/0044-8486(79)90123-6

Ling, S.W., 1977. Snakehead, ophiocephalus spp. culture. In: Aquaculture in Southeast Asia: A historical overview (ed. S.W. Ling): University of Washington Press, Seattle, pp. 60-66.

Mehboob, S., Sheri, A.N. and Raza, S.H., 1996. Proximate composition of major, common and some Chinese carps as influenced by pond fertilization and feed supplementation in composite culture system. J. Aquacult. Trop., 11: 227-284.

Malik, A., Waryani B., Kalhor, I.B., Kalhoro, H., Shah, S.A. and Narejo, N.T., 2014. To observe the effect of growth performance and adaptation of exotic fish red tilapia (hybrid) in climate of Fish Hatchery Chilya, Thatta, Sindh-Pakistan. Sindh Univ. Res. J. (Sci: Ser), 46: 461-464.

Malik, A., Abbas, G., Kalhoro, H., Kalhoro, I.B., Shah, S.A. and Kalhoro, H., 2017. Optimum salinity level for seed production and survival of red tilapi (Hybrid) in concrete tanks. Pak. J. Zool., 49: 104 1056.

Marimithu, K., Haniffa, M.A., Muruganandam, M. and Arockiarak, A.J., 2001a. Low cost murrel seed production technique for fish farmer. Naga. 24: 2122.

Marimithu, K., Haniffa, M.A., Arockıarak, A.J. and Muruganandam, M.,2001b. Spawning and parental behavior in the induced breed murrels. Indian $J$. Fish 48: 409-411.

Matjais, A.M., Mccultock, R. and Croft, K., 1994. Fatty acid and amino acid composition in Haruan as a potential role in wound healing. Gen. Pharmacol., 25: $\quad 947-950 . \quad$ https://doi.org/10.1016/03063623(94)90101-5

Michelle, N.Y.T., Shanthi, G. and Loqman, M.Y., 2004. Effect of orally administered Channa striatus extract against experimentally induced osteoarthritis in rabbits. Int. J. appl. Res. Vet. Med., 2: 171-175.

Mohanty, S.S. and Samantaray, K., 1996. Effect of varying level of dietary protein on the growth performance and feed conversion efficiency of snakehead, Channa striatus. Aquacult. Nutr., 2: 89-94. https://doi.org/10.1111/j.1365-2095.1996. tb00013.x

Mollah, M.F.A., Mamum, M.S.A., Sarowar, M.N. and
Roy, A., 2009. Effect of stocking density on growth and breeding performance of brood fish and larval growth and survival of soul, Channa striatus (Bloch). J. Bangladesh Agric. Uni., 7: 427-432.

Moreira, I.S., Peres, H., Couto, A., Enes, P. and Oliva-Teles, A., 2008. Temperature and dietary carbohydrate level effects on performance and metabolic utilization of diets in European sea bass (Dicentrarchus labrax) juveniles. Aquaculture, 274: $\quad 153-160 . \quad \mathrm{https}: / /$ doi.org/10.1016/j. aquaculture.2007.11.016

Narejo, N.T., Dayo A., Dars, B.A., Mahesar, H., Laghari, M.Y. and Lashari P.K, 2010. Effect of stocking density on growth and survival rate of Labeo rohita (Hamilton) fed with formulated feed. Sindh Univ. Res. J. (Sci.

Ng, P.K. and Lim, K.K.P., 1990. Snakeheads (Pisces: Channidae): natural history, biology and economic inportance. In. Essays in zoology (eds. C.L. Ming and P.K.L. Ng), Papers commemorating the $40^{\text {th }}$ Anniversary of the Department of Zoology, National University of Singapore, pp. 127-152.

Qgino, C. and Saito, K., 1970. Protein nutrition in fish. The utilization of dietary protein by young carp. Bull. Jap. Soc. scient. Fish., 36: 250-254.

rather, E.B. and Lovell, R.T., 1973. Responses of intensively fed channel catfish to diets containing various protein energy ratios. Proc. S. E. Assoc. Game Fish Comm., 27: 455-459.

Qin, J.G. and Fast, A.W., 1997. Food selection and growth of young snakehead, Channa striatus. J. appl. Ichthyol., 13: 21-25. https://doi. org/10.1111/j.1439-0426.1997.tb00093.x

Qin, J.G. and Fast, A.W., 2003. Intensive culture of snakehead, Channa striatus during larval, juvenile and growth stages. Am. Fish. Soc. Symp., 38: 33-41.

Shah, S.A., Malik, A., Kalhoro, H., Kalhoro, I.B., Wadhar, G.M. and Maher, G.M., 2014. Growth performance of exotic catfish Pangas, Pangasius hypophthalmus (Sauvage, 1878) at Fish Hatchery Chilya Thatta, Sindh, Pakistan. Sindh Univ. Res. J. (Sci. Ser.), 46: 205-208.

Singh, B.R., Prasad, M.S. and Mishra, A.P., 1986. Oxygen uptake through water during early life in Channa striatus (Bloch). Pol. Arch. Hydro. Biol., 33: 97-104.

Sonawane, S., Gedam, A., Anand, S. and Pawar, S., 2012. Food and feeding habits of Channa punctatus from Kaigaon Toka Dist. Aurangabad (M.S.) in relation to biochemical studies. J. exp. Sci., 3: 7-13. Srivastava, P.P., Dayal, R., Chowdhary, S., Jena, J.K., Raizada, S., Sharma, P., 2012. Rearing of fry to 
fingerling of Soul (Channa striatus) on artificial diets. Online J. Anim. Feed Res., 2: 155-161.

Soto-Zarazúa, G.M., Herrera-Ruiz, G., Rico-García, E., Toledano-Ayala, M., Peniche-Vera, R., OcampoVelázquez, R. and Guevara-González, R.G., 2010. Development of efficient recirculation system for tilapia (Oreochromis niloticus) culture using low cost materials. Afr. J. Biotechnol., 9: 5203-5211.

Suloma, A. and Ogata, H.Y., 2006. Future of rice-fish culture, desert aquaculture and feed development in Africa: the case of Egypt as the leading country in Africa. Japan Agric. Res. Quar, 40: 351-360. https://doi.org/10.6090/jarq.40.351

Teng, S.K., Chua, T.E. and Lim, P.E., 1978. Preliminary observation on the dietary protein requirement of estuary grouper, Epinephelus salmoides Maxwell, cultured in floating net cages. Aquaculture, 15: 257 289. https://doi.org/10.1016/0044-8486(78)900376

Van Densen, W.L.T., 1985. Feeding behaviour of major $0+$ fish species in a shallow, eutrophic lake (Tjeukemeer, The Netherlands), J. appl. Ichthyol., 1: 49-70. https://doi.org/10.1111/j.1439-0426.1985. tb00412.x
Wee, K.L., 1982. The biology and culture of snakeheads. In: Recent advances in aquaculture (eds. J.F. Muir and R.J. Roberts). Westview Press, Boulder, Colorado, USA, pp. 180-211.

Wee, K.L., 1986. A preliminary study on the dietary protein requirements of juvenile snakehead. In: Proc. Int. Conf. Dev. Manage. Trop. Living Aquat. Resources, Serdang, Malaysia, 2-5 Aug, 1983, pp. 131-136.

Wee, K.L. and Tacon, A.G.J., 1982. A preliminary study on the dietary protein requirement of juvenile snakehead (Channa micropeltes). Bull. Jap. Soc. Sci. Fish., 48: 1463-1468. https://doi.org/10.2331/ suisan.48.1463

Yakoob, W.A.A. and Ali, A.B., 1992. Simple method for backyard production of snake head (Channa striata Bloch) fry. Naga, 15; 22-23.

Zakaria, Z.A., Mat-Jais, A.M., Goh, Y.M., Sulaiman, and Somchit, M.N., 2007. Amino acid and fatty acid composition of an aqueous extract of Channa striatus (Haruan) that exhibits antinociceptive activity. Clin. exp. Pharmacol. Physiol., 34: 198-204. https://doi.org/10.1111/ 40-1681.2007.04572.x

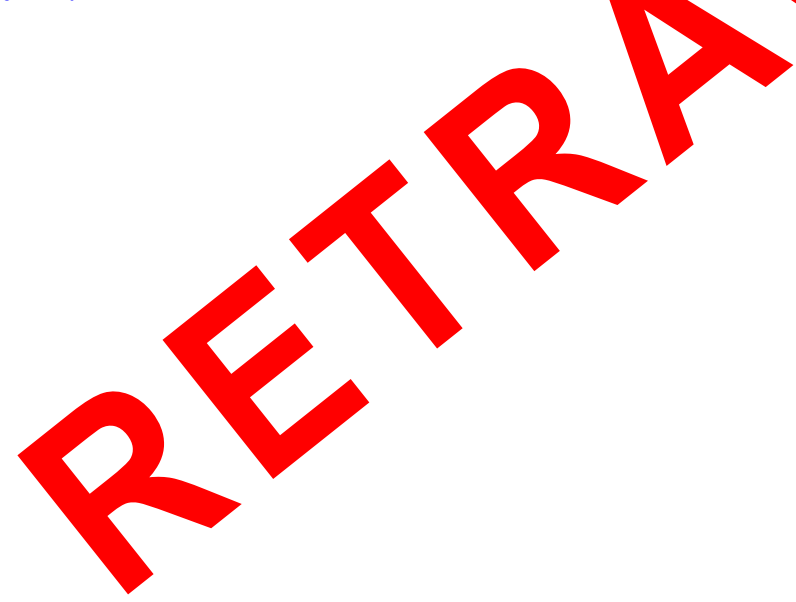

